\begin{tabular}{|c|c|}
\hline \multirow{3}{*}{ 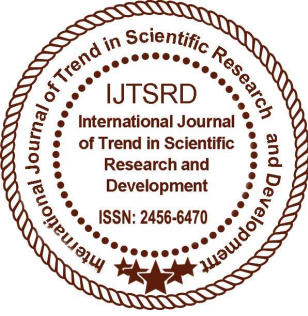 } & $\begin{array}{l}\text { International Journal of Trend in Scientific } \\
\text { Research and Development (IJTSRD) }\end{array}$ \\
\hline & International Open Access Journal \\
\hline & ISSN No: 2456 - 6470 | www.ijtsrd.com | Volume - 2 | Issue - 4 \\
\hline
\end{tabular}

\title{
A review paper on comparative analysis of Diesel blends with different proportions of karanja oil Biodiesel
}

\author{
Ajeet Kumar Prajapati, Vipin Kumar Patel \\ Research Scholar (PG), Department of Mechanical Engineering, University Institute of technology, \\ Rajiv Gandhi Prodyogiki Vishwavidyalaya, Bhopal, Madhya Pradesh, India
}

\begin{abstract}
Biodiesel is an attracted alternative fuel and biodiesel-diesel blends can be used as fuel in order to substitute some part of diesel in engine at various applications. In this study, the spray properties of different type of blends of biodiesel-diesel (25\%, $50 \%, 75 \%$ and $100 \%$ biodiesel) as well as pure diesel is investigated under various ambient conditions by means of high-speed schlieren photography technique. A comparative analysis of blended fuels and diesel sprays is also presented. The experimental results show that when adopting fuel blends with variable biodiesel-diesel fractions in the swirl-type injector sprays, the spray developing patterns are not significantly changed. In the case of low ambient pressure (surrounding condition), the main spray tip penetration decreases and the spray angle increases with the increase of biodiesel fraction. Under the elevated ambient pressure condition, the difference of spray penetration amongst the blends shows inconspicuous, meanwhile the spray angle of all test fuels keeps almost constant in the fully developed stage except that the spray of pure diesel shows a larger cone angle in the beginning of injection period.
\end{abstract}

Keywords: Biodiesel, spray, Blends

\section{INTRODUCTION}

Due to the increasing energy requirement day by day in the various field like that transportation, industry, lighting, cooking

etc .so that fossil fuel resources inevitably necessitate for the best possible utilization of exhaustible fossil fuel and non-renewable energy resources. Alternatives hold the key to the future of the automobile industry. There is tremendous potential both in terms of performance as well as reduced health risks. But the automobile sector has failed to show any real interest in these fuels. Consider this: the use of alternative fuels can reduce the risk of cancers by as much as 90 per cent. They are much more fuel-efficient and require less maintenance. Yet alternative fuels constitute less than one per cent in the automobile segment. Today there are many alternatives: compressed natural gas (cng), liquefied petroleum gas (lpg), methanol, hydrogen fuels, electricity, solar energy and bio-diesel. And the advantages are many:

\section{Alternative technology}

Many in the auto industry believe that the era of alternatives to ic engine is about to dawn. This is because futuristic fuel cells engine and electric cars are slowly inching towards commercial viability and hybrid vehicles have already achieved a high degree of success in Japan. Like hybrid, fuel cell is also another ecofriendly option. In principle, a fuel cell operates like a battery. It has the potential to be substantially more efficient than a conventional ic engine. One of the major advantages of fuel cell is that while current 
internal combustion engines have efficiency in the range of 20 per cent, the fuel cells efficiency is generally above 30 per cent. There are certain inherent disadvantages in alternative fuels and there is need to promote and develop the sector. But there is no denying that alternative fuel operated on alternative fuel vehicles will soon become a common sight in the automobile industry due to improved efficiency and reduced emissions. While some countries in Europe are moving in this direction, the initiative is yet to gain momentum in India. This is mainly because the industry has not been proactive in switching to cleaner fuels. The blame is also on the Union government, which has played into the hands of the petrol/diesel lobby to frustrate any attempts to bring about any real change.

\section{BIODIESEL COMPOSITION:}

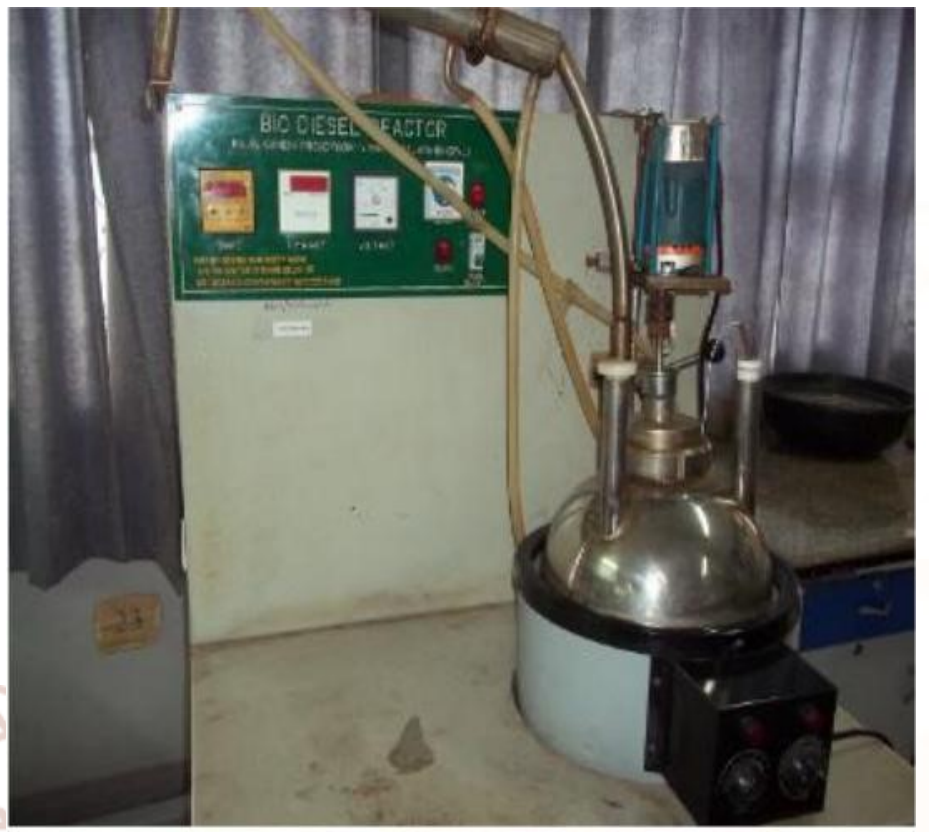

Production of Karanja Oil Biodiesel India is a tropical country and avails most favourable climate for the growth of karanja tree. It is found in abundance in rural areas and woods of whole India, especially in eastern part of India and Western Ghats. Another name of the karanja is pongamiapinnata. The raw karanja oil was obtained from karanja seeds and then it was subsequently converted into its respective biodiesel i.e., karanja oil methyl ester.Fig.1 shows the close view of karanja seeds. The seeds are crushed in expeller to acquire the oil. Anoutlook of raw/ oil obtained by the process of crushing the seeds has been given in Fig. 2 As the tree of karanja is naturally found in forest, there is so far no reports on adverse effects of karanja on fauna, flora, and humans or even on environment but that is a different area of research.Karanja oil is non-edible and hence further encourages its application for biodiesel production.
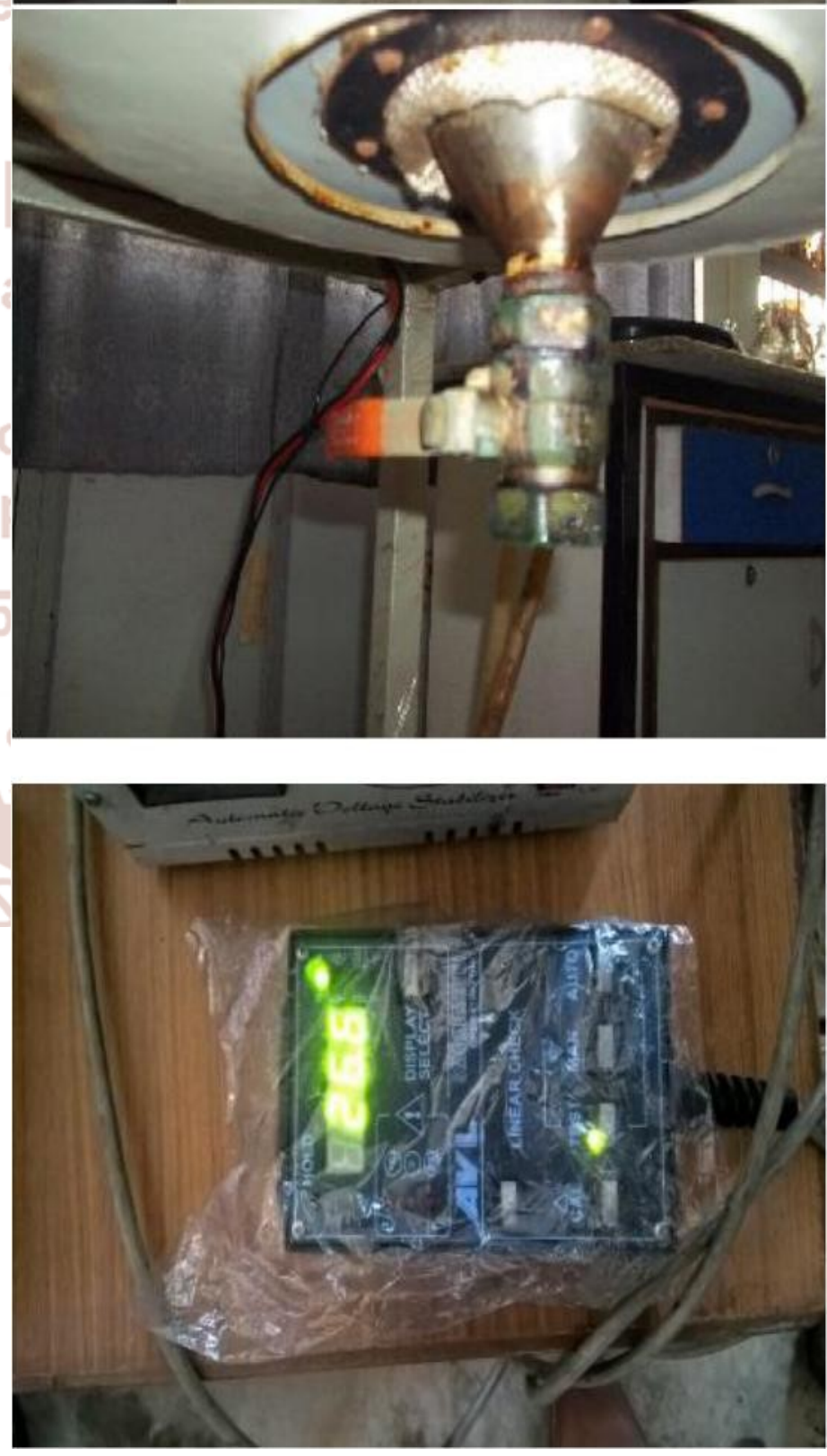

Figure: UIT RGPV lab 
Biodiesel is fatty acid alkyl ester obtained by transesterification process of vegetable oils, animal fats and waste oils. It has similar composition and properties as that of petroleum diesel. The replacement phenomenon of an alcohol by a different alcohol from an ester is known as transesterification, the process of transesterification is also known as alcoholises. By the help of this process we reduce down the viscosity of triglycerides. The general equation of transesterification is

RCOOR'+

R"OH RCOOR" + R'OH

Where,

R, R' \&R" denote Alkyl or Aryl group

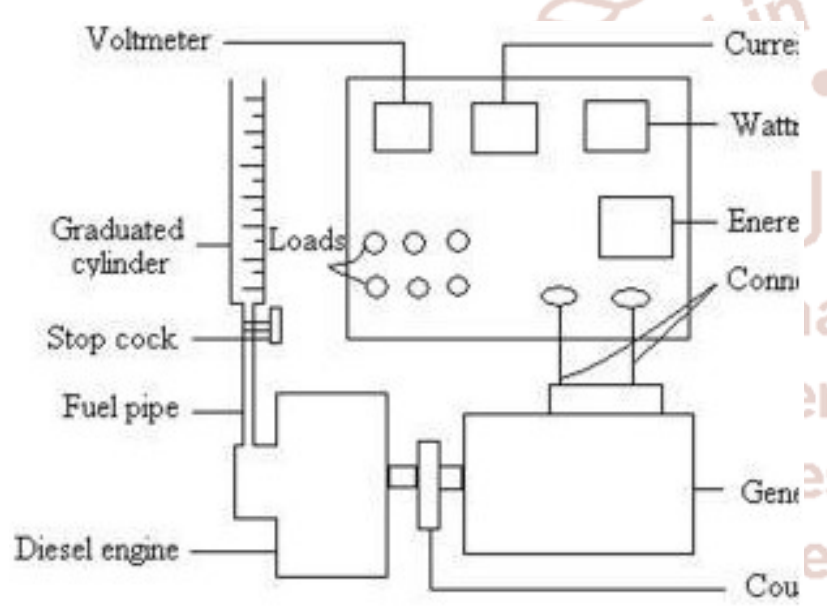

Figure: Block diagram of engine set up

In the above reaction if methanol is used, it is termed methanolysis. Fig 3 shows the image of the reactor in which the tansesterification process took place. Raw materials required:

- Karnaja seed oil

- Lye (Catalyst)

- Methanol

- Isopropyl Alcohol (for tests. Use 99\% IPA)

\section{B20:}

B20 is a common biodiesel blend in the United States. B20 is popular because it represents a good balance of cost, emissions, cold-weather performance, materials compatibility, and ability to act as a solvent. Most biodiesel users purchase B20 or lower blends from their normal fuel distributors or from biodiesel marketers. Regulated fleets that use biodiesel blends of $20 \%$ (B20) or higher qualify for biodiesel fuel use credits under the energy Policy Act of 1992. B20 must meet prescribed quality standards as specified by ASTM D7467-17. The U.S. Department of Energy's Vehicle

Technologies Office has supported work to test and improve biodiesel quality, helping more fuel meet ASTM standards. B20 and lower-level blends can be used in current engines without requiring modifications. Engines operating on B20 have similar fuel consumption, horsepower, and torque to engines running on petroleum diesel. B20 with $20 \%$ biodiesel content will have $1 \%$ to $2 \%$ less energy per gallon than petroleum diesel, but most B20 users report no noticeable difference in performance or fuel economy. Biodiesel also has some emissions benefits, especially for engines manufactured before 2010. For engines equipped with selective catalytic reduction (SCR) systems, the air quality benefits are the same whether running on biodiesel or petroleum diesel. However, biodiesel still offers better greenhouse gas benefits compared to conventional diesel fuel. The emissions benefit is roughly commensurate with the blend level; that is, B20 would have $20 \%$ of the emissions reduction benefit of $\mathrm{B} 100$.

\section{B100 and High-Level Blends}

B100 and other high-level biodiesel blends are less common than B20 and lower blends due to a lack of regulatory incentives and pricing. Biodieselcompatible material for certain parts, such as hoses and gaskets, allow B100 to be used in some engines built since 1994 . B100 has a solvent effect, and it can clean a vehicle's fuel system and release deposits accumulated from petroleum diesel use. The release of these deposits may initially clog filters and require frequent filter replacement in the first few tanks of high-level blends.

When using high-level blends, a number of issues should be considered. Pure biodiesel contains less energy on a volumetric basis than petroleum diesel. Therefore, the higher the percentage of biodiesel (above 20\%), the lower the energy content per gallon. High-level biodiesel blends can also impact engine warranties, gel in cold temperatures, and may present unique storage issues. B100 use could also increase nitrogen oxides emissions, although it greatly reduces other toxic emissions. 


\section{Spray quality}

\section{Fuel Quality:}

It is important that when you are purchasing fuel you make sure it is high quality by meeting all ASTM specifications. Fuel that is off specification on just one of the ASTM standards can not only cause serious engine problems, but it can void engine warranties if it is determined that the fuel caused damage. This can cause unnecessary costly repairs for vehicles/equipment. To review specifications for diesel fuel, biodiesel and biodiesel blends, see the specifications in the Appendix. In an effort ensure that producers and marketers operate in a manner consistent with proper specifications, the National Biodiesel Accreditation Commission created the BQ9000 program in 2005. This voluntary program establishes quality systems for producers and marketers of biodiesel in the areas of storage, sampling, testing, blending, shipping, distribution and fuel management practices. If purchasing $\mathrm{B} 100$ or a biodiesel blend, ask if the biodiesel is from a BQ9000 biodiesel producer/marketer. If you are unable to get fuel from a BQ-9000 producer/marketer, the next best thing is to verify with your supplier that the fuel meets all ASTM specifications.

\section{Blending Your Own Fuel:}

First be sure the (D975) diesel and (D6751) biodiesel blending components all meet ASTM specifications as showing the Appendix and that biodiesel is BQ9000 certified. Biodiesel Stock (B100) and biodiesel blends must be clean in appearance and free of water and sediment. Fuel that is not clear and bright indicates either poor fuel handling and/or storage practices, or poor fuel quality. Biodiesel blending procedures depend on a variety of factors, including the volume of B100 required to make the blend, the finished blend level, the volume of blended products being sold, tank and space availability, and equipment and operational costs. The temperature of the biodiesel should be a minimum of $60^{\circ} \mathrm{F}$ or $10^{\circ} \mathrm{F}$ above the cloud point when being blended. In-line blending, properly designed and executed (as done at refineries and pipeline terminals in Minnesota), is the best way to ensure complete blending of biodiesel and diesel fuel. Splash blending, however, (blending of diesel and biodiesel in separate streams into a transport or truck tank) may be used in locations where in-line blending is not available. For top loading trucks in warm weather, if possible load both products at the same time through separate lines at high enough fill rates to sufficiently mix the products in the tank. If diesel and biodiesel must be added separately or at separate locations, it is recommended that the diesel fuel be loaded first, then biodiesel be introduced with as high volume and velocity as possible to enhance thorough blending. It is important that the $\mathrm{B} 100$ is kept at least $10^{\circ} \mathrm{F}$ above the cloud point while blending takes place. An empty truck tank can be so cold that in a short time, biodiesel can cool and gel on the tank bottom before blending takes place. If in-line blending for top loading trucks is not available in cold weather, first add half the diesel (warm if possible). Then, as quickly as possible, add warm $\left(60^{\circ} \mathrm{F}\right.$ or more $)$ biodiesel at high pressure and volume to enhance thorough mixing followed by the other half of the diesel fuel. Splash blending may also be done in bottom loading transports. For bottom loading in warmer weather, the biodiesel is loaded in the tank through the manifold system first, followed by the diesel fuel. A homogeneous mixture should be obtained if the flow rate of the diesel fuel is adequate (several hundred gallons per minute) If in-line blending is not available for bottom loading trucks in cold weather, it is important that the B100 is kept at least $10^{\circ} \mathrm{F}$ above the cloud point (preferably $60^{\circ} \mathrm{F}$ or more) while blending takes place. An empty truck tank can be so cold that in a short time, biodiesel can cool and gel in the manifold before blending takes place. Therefore, in cold conditions, introduce half the diesel fuel (warm if possible) through the manifold first, then add warm biodiesel $\left(60^{\circ} \mathrm{F}\right)$ at a high volume and pressure through a port in the top of the tank to get maximum turbulence. Finally, introduce the other half of the diesel through the bottom manifold with as high pressure and volume as possible. Further agitation may be necessary to achieve a homogeneous blend. The start and stop action of the truck during delivery can be helpful and, if the entire load is pumped into the customer storage tank, this action will usually be enough to cause complete mixing. For more detailed recommendations on splash blending talk to your supplier. B100 should be stored at temperatures of at least $50^{\circ} \mathrm{F}$ or $10^{\circ} \mathrm{F}$ higher than its cloud point (which can vary depending on the source) prior to blending with petroleum diesel to ensure adequate blending. Depending on the climate and storage method, insulation, agitation, heating systems or other methods to maintain the targeted temperature may be required. 


\section{D975 No. 2 Diesel Fuel:}

Biodiesel blends up to 5 percent are considered no different than conventional No. 2 petroleum diesel. These blends will meet the ASTM D975 fuel specification and can be used in any application as if they were pure petroleum diesel. No special labelling is required at retail pumps to inform consumers that biodiesel is contained in the fuel.

\section{Methodology for performance testing:}

The engine was directly coupled to alternator and loaded by electrical resistance. The separate fuel measurement unit was connected with engine. A resistive load panel was attached with the output of the generator. The engine-generator set was run initially using diesel for $10 \mathrm{~min}$ each for $25 \%, 50 \%$, $75 \%$ and $100 \%$ load. The fuel consumption was measured by using stopwatch. At the same time the readings of voltmeter, current meter and energy meter were also noted down. Different blends of PB, WCB with diesel were prepared. The filter of diesel engine was opened and complete mixture of biodiesel and diesel was drained so that it could not mix with the next blend. The experiment was repeated-for each blend to enhance the accuracy of the blend.

\section{Result and discussion:}

The load test results were processed to compare the BSFC of all the biodiesels considered in the study.

Fig. 3 shows the variation of BSFC of PB100, WCB100,WCB10:PB10:D80, WCB20:PB20:D60 and WCB30:PB30:D40 with load

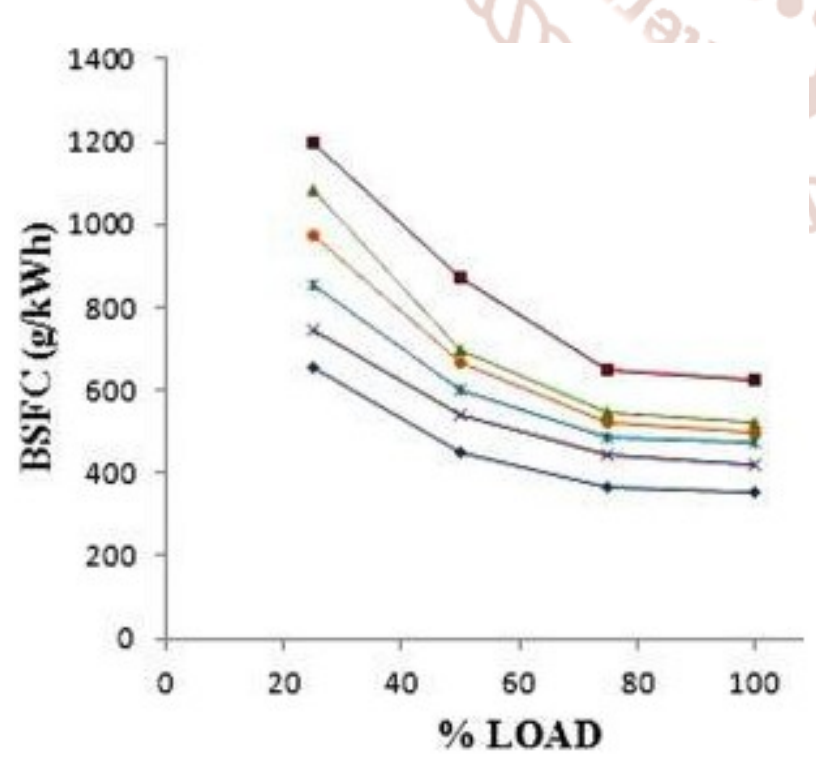

It's evident from Fig. 3 that BSFC of PB100 is highest at all loads from other biodiesels while WCB100 has much lower BSFC than that of PB100. When the load is $25 \%$, BSFC of PB100 is $10.8 \%$ higher than that of WCB100 but at $50 \%$ loading the BSFC gap between PB100 and WCB100 gets wider with PB100 BSFC being $46.8 \%$ higher. The BSFC of WCB100 is higher than ternary blend of WCB20:PB20:D60.

At 25\% loading BSFC of WCB10:PB10:D80 is $24 \%$ higher than that of diesel. The BSFC of WCB10:PB10:D80 is comparable to diesel at all loading conditions. The result of BSFC for PB100 and WCB100 is in agreement with previous work done by various researchers .

As per the test results shown in Fig. 4 BTE of WCB100 remains higher than PB100. At 25\% load the BTE of WCB10:PB10:D80 $12.63 \%$ is almost equal to the BTE of diesel $12 \%$. The BTE of PB100 and WCB100 are lower than ternary blend and diesel in all loading conditions. The engine performance results show that ternary blend performance is comparable to that of diesel.

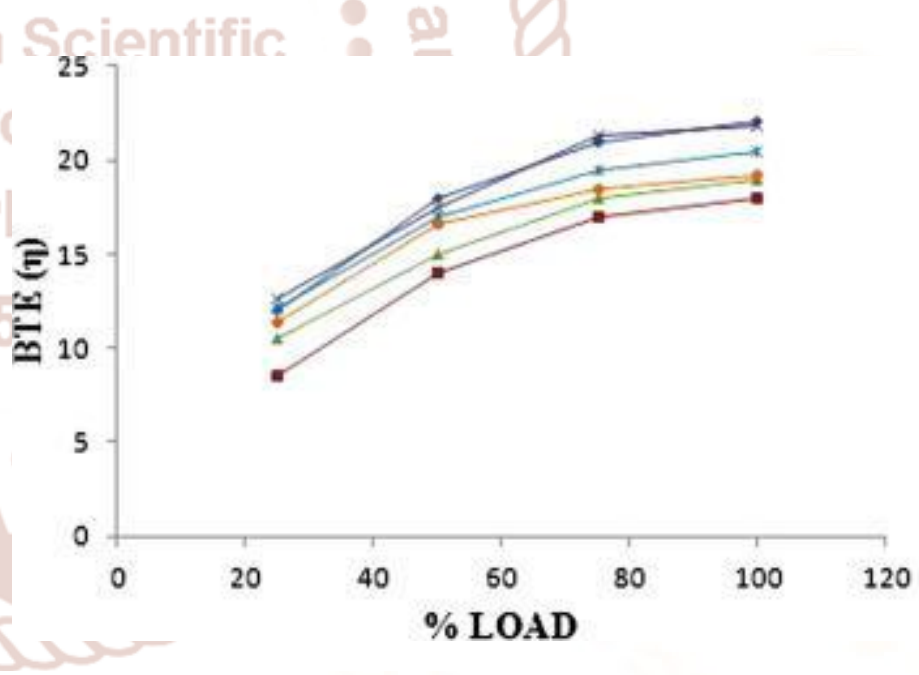

\section{Findings:}

The result of investigation of PB100, WCB100, diesel and their ternary blends reveals that:

(1) High viscosity and lower calorific value of PB100 and WCB100 as compared to diesel are main obstacles in the development of these biodiesels as an alternative fuel to diesel.

(2) Poor cloud and pour point make it difficult to use PB100 and WCB100 to be used as fuel in cold climatic condition. 
(3)The cold flow properties of ternary blend WCB10:PB10:D80 are comparable to diesel and make it suitable to be used as fuel in cold climatic condition.

(4) The BSFC and BTE of ternary blend are higher at $25 \%$ loading comparable to diesel and it is much better as compared to PB100 and WCB100.

(5)The $\mathrm{HC}$ and $\mathrm{CO}$ emissions are lower in case of all blends of biodiesel as compared to diesel while $\mathrm{NOx}$ emission is lower in case of diesel.

\section{Conclusions}

The experiment investigation shows that biodiesel from Pongamia and waste cooking oil can be developed as alternate fuel for future. The fuel properties like density, viscosity and calorific value of ternary blend of PB and WCB and diesel are more or less comparable to diesel. The cloud point and pour point of various biodiesel blends are higher than those of diesel. As the percentage increases in biodiesel concentration, it will further result in an increase in cloud and pour point of biodiesel due to the presence of various fatty acids in it. The ternary biodiesel blends of (WCB10:PB10:D80) have cloud point and pour point of $6.5^{\circ} \mathrm{C}$ and $6{ }^{\circ} \mathrm{C}$, respectively which are comparable to cloud and pour point of diesel $6{ }^{\circ} \mathrm{C}$ and $5{ }^{\circ} \mathrm{C}$, respectively. The engine testing result shows that at higher loads the BSFC of WCB10:PB10:D80 is higher than that of diesel but at $25 \%$ loading it is comparable to diesel. The BTE of ternary blend is nearly same as that of diesel at $25 \%$ loading with $12 \%$ and $12.63 \%$, respectively. The $\mathrm{HC}$ and $\mathrm{CO}$ emissions are also lower in case of biodiesel and its blends while NOx emission is lower for diesel. The investigation shows the ternary blend has improved engine performance to a greater extent as comparable to that of diesel.

\section{References:}

1) M.G. Kulkarni, A.K. Dalai Ind. Eng. Chem. Res., 45 (2006), pp. 2901-2913 CrossRefView Record in Scopus

2) K. Pramanik Renewable Energy, 28 (2003), pp. 239-248 ArticleDownload PDFView Record in Scopus

3) J. Cvengros, F. Povazanec Bioresour. Technol., 55 (1996), pp. 145-152 View Record in Scopus

4) F.R. Ma, M.A.F. Hanna Bioresour. Technol., 70 (1999), pp. 1-15 ArticleDownload PDFView Record in Scopus

5) A.K. Agarwal Prog. Energy Combust. Sci., 33 (2007), pp. 233-271 ArticleDownload PDFView Record in Scopus

6) L. Raslavicius, Z. Bazaras Fuel Process. Technol., 91 (2010), pp. 1049-1054 ArticleDownload PDFView Record in Scopus

7) G. Dwivedi, M.P. Sharma, S. Jain Int. J. Energy Sci., 1 (2) (2011), pp. 105-109 View Record in Scopus

8) N.U. Soriano Jr., V.P. Migo, K. Sato, M. MatsumuraFuel, 85 (2006), pp. 25-31 ArticleDownload PDFView Record in Scopus

9) O.M.I. Nwafor, G. Rice, A.I. Ogbonn Renewable Energy, 21 (2000), pp. 433-444 ArticleDownload PDFView Record in Scopus

10) A. Sarin, R. Arora, N.P. Singh, R. Sarin, R.K. Malhotra, K. Kundu Energy, 34 (2009), pp. 20162021ArticleDownload PDFView Record in Scopus

11) G. Dwivedi, M.P. Sharma, S. Jain J. Mater. Environ. Sci., 4 (4) (2013), pp. 434-447 View Record in Scopus

12) Y. Icingur, D. Altiparmak Energy Convers. Manage., 44 (2003), pp. 389-39 